\title{
Sensitive spectrophotometric method for determination of catecholamines in pure and pharmaceutical formulations
}

Thabit S. Al-Ghabsha ${ }^{a}$

Mohammed S. Al-Enizzi ${ }^{\text {b }}$

Zeena Z. Al-Abdaly ${ }^{\mathrm{a}}$

${ }^{\text {a }}$ Chemistry department, College of Education

${ }^{\mathrm{b}}$ Basic Sciences branch , College of Agriculture and Forestry Mosul University

Received

Accepted

11/9/2006

5/12/2006

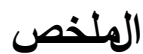

تم تطوير طريقة طيفية سهلة وحساسة لتقدير كميات مايكروغرامية من أدوية أمينات

الكاتيكول المتمثلة بالمثيل دوبا ودوبامين وادرينالين تعتمد الطريقة على أكسدة تلك الأدوية

بوساطة الحديد الثلاثي في وسط حامضي ومفاعلة الحديد الثنائي الناتج مع الكاشف 10،

فينانثرولين وقياس معقد الفيروين الملون عند طول موجي

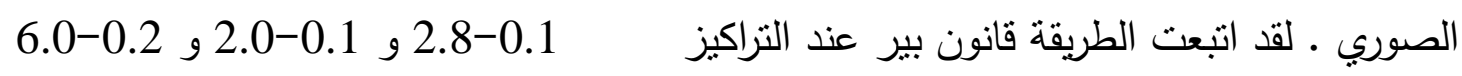

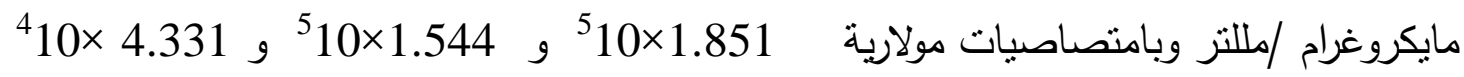
لتر/مول.سم لكل من المثيل دوبا ودوبامين وادرينالين على التوالي ـ كما أن الطريقة لاتعاني من تداخلات من وجود مواد السواغ وأمكن تطبيق الطريقة بنجاح في تقدير تلك الأدوية في مستحضراتها الصيدلانية.
\end{abstract}

\section{Abstract}

A sensitive and simple spectrophotometric method is developed for the determination of catecholamine drugs namely; methyldopa, dopamine and adrenaline in pure and pharmaceutical preparations. The method is based on the oxidation of the cited drugs with iron(III) in acidic medium and the liberated iron(II) reacts with 1,10-phenanthroline. The ferroin complex is colorimetrically measured at $510 \mathrm{~nm}$ against reagent blank. Beer's law was valid over the concentration ranges of 0.1-2.8, 0.1-2.0, and $0.2-6.0 \mu \mathrm{g} / \mathrm{ml}$ and the molar absorptivities are $1.851 \times 10^{5}, 1.544 \times 10^{5}$ and $4.331 \times 10^{4} 1 . \mathrm{mol}^{-1} \mathrm{~cm}^{-1}$ for methyldopa, dopamine and adrenaline respectively. The common excipients and additives did not interfere in their determinations. The proposed method was successfully applied to the assay of the above drugs in various dosage forms.

Keyword: Spectrophotometry; Catecholamines; Ferric chloride;1,10Phenanthroline. 


\section{Introduction}

Methyldopa[amethyl3,4dihydroxyphenylalanine](I),dopaminehydrochlor ide[4-(2-aminoethyl)benzene-1,2-diolhydrochloride](II)andadrenaline[(R)-1(3,4-dihydroxyphenyl)-2 methylaminoethanol](III) are known as catecholamines, which play important roles in the central nervous system as neurotransmitters and widely used to treat hypertension, bronchial asthma, cardiac arrest, myocardial infarction, and cardiac surgery[1]. Therefore, a highly sensitive method is necessary for the determination of the catecholamines, both in pharmaceutical samples and biological fluids.

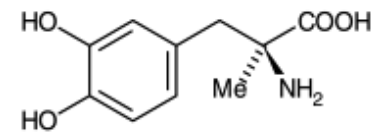

(I)

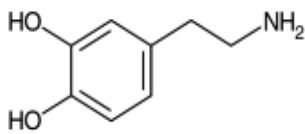

(II)

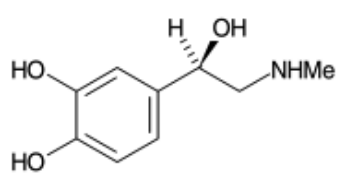

(III)

A variety of techniques have been utilized for the determination of catecholamines, such as chromatography[2-4], capillary electrophoresis[5-7], fluorometry[8-10], and electrochemical detection $[11,12]$. However, these methods are complicated since they need derivatization or combination with various means of detection.

Many spectrophotometric methods have been proposed for the determination of catecholamines using several reagents such as vanillin [13], 2,3,5-triphenyltetrazolium chloride [14], semicarbazide hydrochloride in the presence of potassium persulphate [15], barbituric acid [16,17], metaperiodate [18], isoniazid in presence of $\mathrm{N}$ bromosuccinamide [19], 4-aminoantipyrine in the presence of copper tetramine[20] polyphenol oxidase enzyme [21], neotetrazolium chloride [22], p-dimethylaminocinnamaldehyde [23], diazotized sulphanilamide in the presence of molybdate [24] and molibdophosphoric acid in sulphuric acid medium [25], anisidine in the presence of sodium metaperiodate [26] and benzidine in the presence of sodium metaperiodate [27].. However, most of these methods suffer from several disadvantages such as the need of the long waiting times [13 - 16] or instability of the coloured species [19], complicated procedure [21], require nonaqueous media [23, 24], or has not been applied to pharmaceutical formulations [25].

The present research aims mainly to develop a sensitive, accurate and economical spectrophotometric method for the determination of methyldopa, dopamine and adrenaline in pure form and in their pharmaceutical preparations based on the oxidation of these drugs with iron(III) and the liberated iron(II) reacts with 1,10-phenanthroline in aqueous solution. 


\section{Experimental}

\section{Apparatus}

All spectral absorbance measurements were carried out on double beam spectrophotometer Shimadzu (UV-160 A) using 1-cm silica cell.

\section{Reagents}

All chemicals used were of analytical reagent grade and chatecholamines standard materials are provided from the state company for drug industries and medical appliances-(SDI) Sammara-Iraq.

\section{Standard solutions of catecholamines $(100 \mu \mathrm{g} / \mathrm{ml})$}

Prepared by dissolving $0.01 \mathrm{~g}$ of each methyldopa, dopamine and adrenaline in distilled water and then the solutions were made up to 100 $\mathrm{ml}$ in a volumetric flask with distilled water and stored in amber coloured bottles in a refrigerator. Working solutions were prepared by further dilution of stock solutions

Iron(III)chloride solution, $0.025 \mathrm{M}$

Prepared by dissolving $0.0231 \mathrm{~g}$ of ferric chloride in distilled water in the presence of $2 \mathrm{ml}$ of $1 \mathrm{M}$ hydrochloric acid and the volume was completed to $100 \mathrm{ml}$ in a volumetric flask with distilled water.

\section{1,10-Phenanthroline solution, 0.025M}

Prepared by dissolving $0.4954 \mathrm{~g}$ of 1,10-phenanthroline in $5 \mathrm{ml}$ of ethanol and the solution was made up to $100 \mathrm{ml}$ in a volumetric flask with distilled water.

\section{General procedure}

Accurately measured volumes containing 0.1-2.8, 0.2-6.0 and 0.1$2.0 \mu \mathrm{g} / \mathrm{ml}$ of methyldopa, dopamine and adrenaline solutions in final dilutions were transferred into a series of $25 \mathrm{ml}$ calibrated flasks. To each of these $0.5,0.25$ and $0.75 \mathrm{ml}$ of $0.025 \mathrm{M} \mathrm{FeCl}_{3}$ solution were added respectively, followed by addition of 3.0 of $0.025 \mathrm{M} \mathrm{1,10-phenanthroline}$ for methyldopa and $2.5 \mathrm{ml}$ for each of dopamine and adrenaline and diluted to the mark with distilled water. The solutions of methyldopa and dopamine were left for $40 \mathrm{~min}$ in water bath adjusted at $80^{\circ} \mathrm{C}$, whereas adrenaline solutions were left for $15 \mathrm{~min}$ at room temperature. The absorbances of the red coloured products were measured at $510 \mathrm{~nm}$ against their respective reagent blank solutions. 


\section{Analysis of dosage forms}

\section{Injection}

Three pharmaceutical injections containing dopamine hydrochloride (200 $\mathrm{mg}$ per $\mathrm{ml}$ ) or adrenaline hydrochloride $(1 \mathrm{mg}$ per $\mathrm{ml}$ ) were mixed well and a volume equivalent to one injection content was diluted appropriately with water to a certain concentration. The concentration of each drug per injection was determined using its respective calibration graph constructed for pure drug by following the general procedure.

\section{Tablet}

Five tablets containing methyldopa drug were weighed and finely powdered, an accurately weighed portion of this powder equivalent to $250 \mathrm{mg}$ was dissolved in distilled water. The resultant solution was filtered through Whatmann no. 41 filter paper into $500 \mathrm{ml}$ standard flask and the filtrate was diluted to the mark by washing the residue with distilled water. An aliquots of this solution containing $0.1-2.8 \mu \mathrm{g} / \mathrm{ml}$ of methyldopa was transferred into a $25 \mathrm{ml}$ volumetric flask and treated in the same way as the standard. The concentration of each drug per tablet was determined using its respective calibration graph constructed for pure drug by following its general procedure.

\section{Results and discussion}

Ferric salts play a prominent role in the spectrophotometric determination of many pharmaceutical drugs ${ }^{[28-30]}$ acting as an oxidant, reducing to ferrous salt its amount corresponds to drug concentration. The amount of $\mathrm{Fe}$ (II) can be determined using 1,10-phenanthroline reagent, and this utilized to develop spectrophotometric method for the determination of methyldopa, dopamine and adrenaline.

\section{Absorption spectra}

Methyldopa, dopamine and adrenaline undergo oxidation by $\mathrm{Fe}$ (III) chloride in acidic medium producing $\mathrm{Fe}(\mathrm{II})$ which subsequently reacted with 1,10-phenanthroline and produces a red coloured complex of tris-1,10-phenanthrolineiron(II) (ferroin) having an absorption maximum at $510 \mathrm{~nm}$ as shown in Fig. 1. 


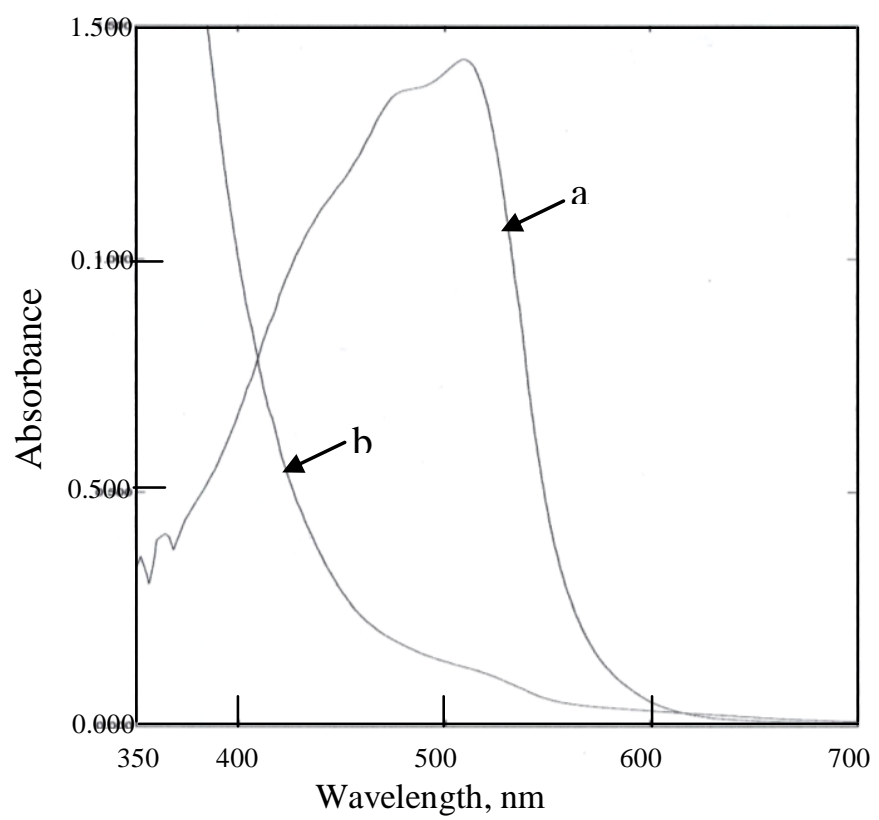

Fig.1.Absorption spectra of (a) $2.0 \mu \mathrm{g} / \mathrm{ml}$ methyldopa containing $0.5 \mathrm{ml}$ of

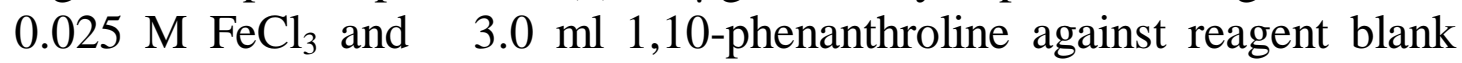
and (b) reagent blank against distilled water.

\section{Optimum reaction conditions}

The optimum reaction conditions for quantitative determination of methyldopa, dopamine and adrenaline were established doing a number of preliminary experiments, via measuring the absorbances of a series of solutions by varying one and fixing the other parameters at $510 \mathrm{~nm}$.

\section{Effect of ferric chloride concentration}

The effect of changing the ferric chloride concentration on the absorbance of solutions containing $2 \mu \mathrm{g} \mathrm{ml}^{-1}$ of each drug were studied. From Fig.2, it is evident that the absorbances increased with increasing ferric chloride concentration and reached maximum when using $0.5,0.25$ and $0.75 \mathrm{ml}$ of $0.025 \mathrm{M}$ ferric chloride for methyldopa, dopamine and adrenaline respectively. More than these volumes leading to decrease the absorbance. Therefore, these volumes were used in all subsequent experiments. 


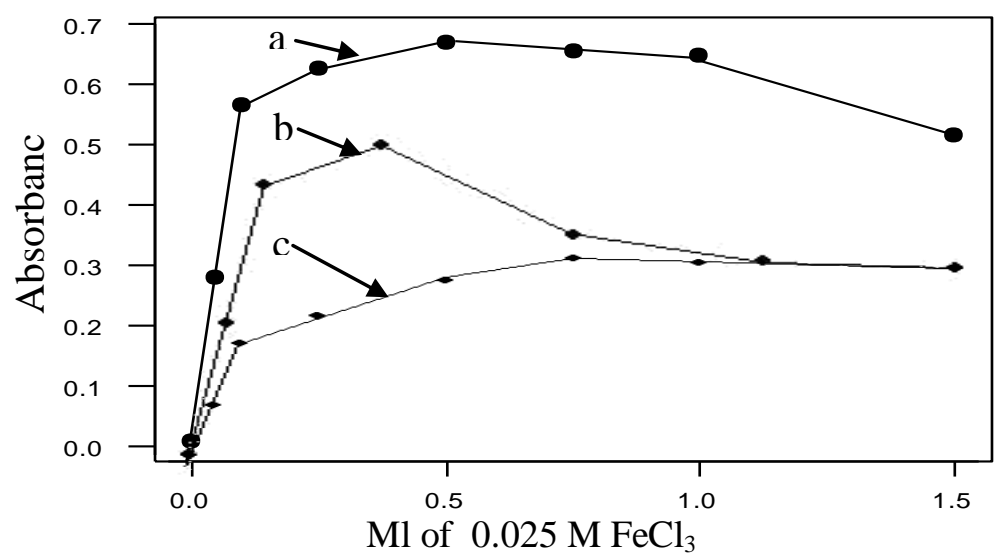

Fig.2. Effect of $\mathrm{FeCl}_{3}$ concentration on the absorption intensity of complexes formed by $1.0 \mathrm{ml}$ of $50 \mu \mathrm{g} / \mathrm{ml}$ of (a) methyldopa, (b) dopamine and (c) adrenaline.

\section{Effect of 1,10-phenanthroline reagent concentration}

The effect of changing the 1,10-phenanthroline concentration on the absorbance of solution containing a fixed amount of catecholamine was studied. It was evident that the absorbance increases with increasing reagent concentration and reached maximum on using a volume of $3 \mathrm{ml}$ of $0.025 \mathrm{M} \mathrm{1,10-phenanthroline} \mathrm{for} \mathrm{methyldopa} \mathrm{and} 2.5 \mathrm{ml}$ for dopamine and adrenaline. More than these volumes caused slightly decreasing in the absorbances. Therefore, these volumes of this concentration were used in all subsequent work.

\section{Effect of temperature and reaction time}

The reaction time was determined by following the colour development at room temperature and at different temperatures in thermostatically controlled water-bath. The absorbance was measured at 5 min intervals against reagent blank treated similarly. It was observed that formation of coloured complex for adrenaline was achieved maximum after $15 \mathrm{~min}$ at room temperature whereas slow and required longer time for completion in the case of methyldopa and dopamine. Hence efforts were made to accelerate the reaction by carrying out the reaction at higher temperatures. It was found that the maximum absorbances for methyldopa and dopamine were obtained after heating the reaction mixture at $80^{\circ} \mathrm{C}$ for $40 \mathrm{~min}$.

\section{Effect of order of addition}

To obtain optimum results the order of addition of reagents should be followed as given under the general procedure, otherwise a loss in colour intensity was observed.

However; the optimum reaction conditions for developing the colour intensity of the complexes are summarized in Table 1. 
Table 1. Optimum reaction conditions for determination of catecholamines.

\begin{tabular}{|c|c|c|c|c|c|c|}
\hline Drug & $\begin{array}{c}\lambda_{\max } \\
(\mathrm{nm} \\
)\end{array}$ & $\begin{array}{c}\mathrm{Temp} \\
\left({ }^{\circ} \mathrm{C}\right)\end{array}$ & $\begin{array}{c}\text { Developm } \\
\text { ent time } \\
(\mathrm{min})\end{array}$ & $\begin{array}{c}\text { Stabilit } \\
\mathrm{y} \\
\text { period } \\
(\mathrm{min})\end{array}$ & $\begin{array}{c}\mathrm{FeCl}_{3} \\
0.025 \mathrm{M} \\
(\mathrm{ml})\end{array}$ & $\begin{array}{c}1,10- \\
\text { phenanthroline } \\
0.025 \mathrm{M}(\mathrm{ml})\end{array}$ \\
\hline $\begin{array}{c}\text { Methyldo } \\
\text { pa }\end{array}$ & 510 & 80 & 40 & $>120$ & 0.5 & 3.0 \\
\hline \begin{tabular}{c} 
Dopamine \\
\hline $\begin{array}{c}\text { Adrenalin } \\
\mathrm{e}\end{array}$
\end{tabular} & 510 & 80 & 40 & $>120$ & 0.25 & 2.5 \\
\hline
\end{tabular}

$*$ Room temperature $=32^{\circ} \mathrm{C}$.

\section{Quantification}

Under the experimental conditions described in Table1, standard calibration graphs were constructed by plotting absorbance versus concentration of each catecholamine as shown in Fig 3. The correlation coefficient, Beer's law limits, molar absorptivity and Sandell sensitivity values were evaluated and are given in Table 2 which are indicating the good linearity and high sensitivity of the method.

Table 2: Summary of optical characteristics and statistics for the proposed method.

\begin{tabular}{|lccc|}
\hline & & & \\
& Methyldopa & Dopamine & Adrenaline \\
\hline$\lambda_{\max }(\mathrm{nm})$ & 510 & 510 & 510 \\
Linearity range $(\mu \mathrm{g} / \mathrm{ml})$ & $0.1-2.8$ & $0.1-2.0$ & $0.2-6.0$ \\
Molar $^{2} \mathrm{absorptivity}$ & $1.8510 \times 10^{5}$ & $1.544 \times 10^{5}$ & $4.331 \times 10^{4}$ \\
$\quad\left(\mathrm{~L} \cdot \mathrm{mol}^{-1} . \mathrm{cm}^{-1}\right)$ & & & \\
Sandell's sensitivity $(\mathrm{ng} / \mathrm{ml})$ & 3.201 & 5.582 & 8.436 \\
Slope & 0.0751 & 0.1013 & 0.1857 \\
Intercept & 0.0078 & -0.0363 & 0.0371 \\
Correlation coefficients & 0.9998 & 0.9989 & 0.9973 \\
\hline
\end{tabular}




\section{Sensitive spectrophotometric method for...}

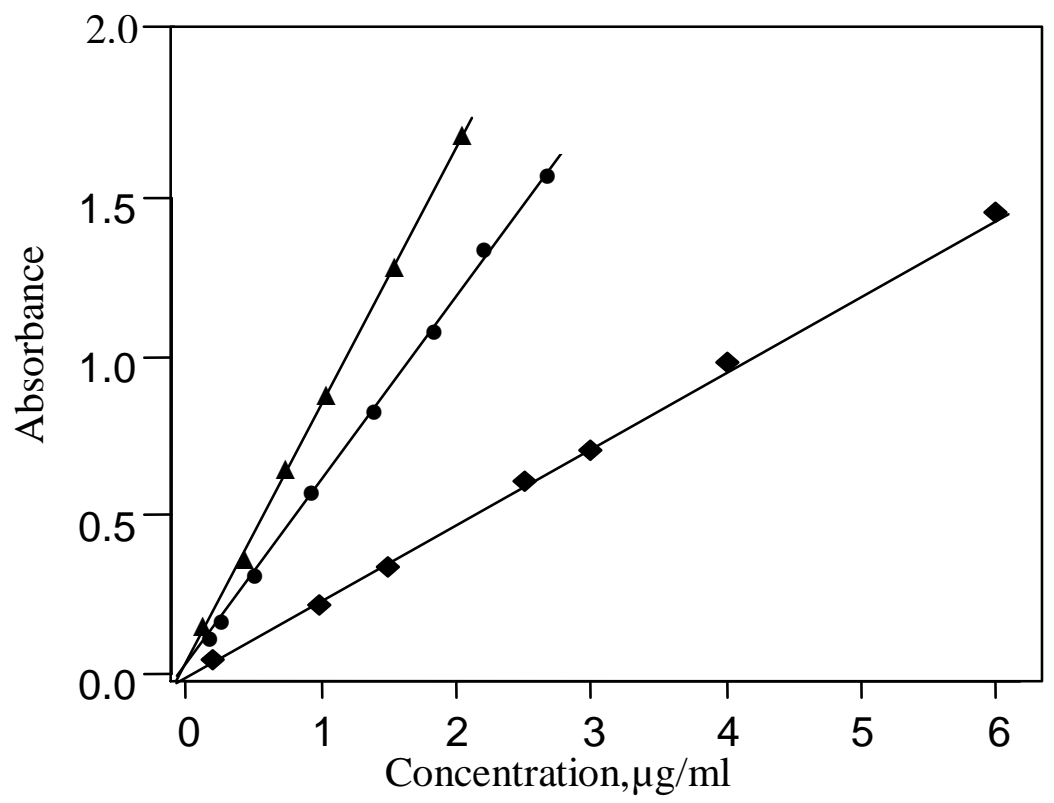

Fig. 3. Calibration graphs of ( $\bullet$ methyldopa, ( $₫$ ) dopamine and $(\bullet)$ adrenaline.

\section{Precision and accuracy}

Six replicate measurements were performed at three different concentrations of each drug. The relative standard deviation and recovery $\%$ results indicated the high precision and accuracy of the proposed method (Table 3).

Table 3. Precision and accuracy data for catecholamine drugs determination obtained by the proposed method

\begin{tabular}{|c|c|c|c|c|}
\hline Compounds & $\begin{array}{c}\text { Amount added } \\
(\mu \mathrm{g} / \mathrm{ml})\end{array}$ & $\begin{array}{c}\text { Recovery } \\
(\%)\end{array}$ & $\begin{array}{c}\text { Average } \\
\text { recovery }(\%)\end{array}$ & $\begin{array}{c}\text { RSD } \\
*\end{array}$ \\
\hline \multirow{3}{*}{ Methyldopa } & 0.4 & 99.93 & & 0.98 \\
& 0.8 & 100.05 & 99.98 & 0.83 \\
\hline \multirow{3}{*}{ Dopamine } & 1.6 & 99.98 & & 0.88 \\
\hline \multirow{3}{*}{ Adrenaline } & 0.2 & 99.03 & & 1.21 \\
& 0.5 & 100.23 & 99.71 & 0.75 \\
& 0.5 & 99.87 & & 1.01 \\
\hline
\end{tabular}

Average of six determinations 


\section{Interference}

In order to assess the possible analytical application of the proposed method the effect of some foreign substances which often accompanied pharmaceutical preparations were studied by adding different amounts, up to $500 \mu \mathrm{g} / \mathrm{ml}$, of foreign substances to $2 \mu \mathrm{g} / \mathrm{ml}$ of adrenaline in final volume of $25 \mathrm{ml}$. The colour was developed following the general procedure described earlier. An error of $\pm 5.0 \%$ in the absorbance readings was considered tolerable from that of the drug alone. It was found that the studied foreign species do not interfere in the present method. Typical results are given in Table 4.

Table 4: Effect of excipients for assay of adrenaline

\begin{tabular}{|c|c|c|c|c|}
\hline \multirow{2}{*}{ Foreign ion } & \multicolumn{4}{|c|}{ Recovery \% of $2 \mu \mathrm{g} / \mathrm{ml}$ of adrenaline per } \\
\cline { 2 - 5 } & 50 & 100 & 250 & 500 \\
\hline Glucose & 103.25 & 102.65 & 104.30 & 102.60 \\
Lactose & 97.10 & 99.50 & 101.35 & 104.30 \\
Benzamide & 96.90 & 99.50 & 96.55 & 96.31 \\
Magnesium stearate & 98.15 & 102.50 & 102.61 & 104.55 \\
Starch maize & 104.52 & 100.45 & 100.25 & 99.05 \\
Sodium chloride & 104.30 & 103.25 & 102.60 & 97.10 \\
Acacia & 106.10 & 104.55 & 102.50 & 99.35 \\
Urea & 104.65 & 104.25 & 103.65 & 96.33 \\
Talc & 99.50 & 99.60 & 103.65 & 104.11 \\
Glycerin & 104.55 & 103.05 & 100.25 & 96.95 \\
& & & & \\
\hline
\end{tabular}

\section{Applications}

The proposed method was applied to determine catecholamines in pharmaceutical formulations. Several commercially available catecholamine formulations including tablets for methyldopa and injections for dopamine and adrenaline were analyzed for their contents without further treatment. On applying the proposed procedure, good recoveries were obtained with these formulations and the results obtained were compared favorably with the British pharmacopoeia method [31], (Table5). 
Sensitive spectrophotometric method for...

Table 5: Assay of catecholamines in pharmaceutical preparations

\begin{tabular}{|c|c|c|c|c|c|}
\hline $\begin{array}{c}\text { Procedure } \\
\text { applied }\end{array}$ & $\begin{array}{c}\text { Pharmaceutical } \\
\text { formulation }\end{array}$ & $\begin{array}{c}\text { Drug amount } \\
\operatorname{present}(\mu \mathrm{g} / \mathrm{ml})\end{array}$ & $\begin{array}{c}\text { Recovery }^{\star} \\
(\%)\end{array}$ & $\begin{array}{l}\text { Average drug } \\
\text { content found } \\
(\mathrm{mg})\end{array}$ & $\begin{array}{l}\text { Certified value } \\
(\mathrm{mg})\end{array}$ \\
\hline \multirow{4}{*}{$\begin{array}{c}\text { Proposed } \\
\text { method }\end{array}$} & $\begin{array}{l}\text { Methyldopa } \\
\text { tablet }^{\mathrm{a}}\end{array}$ & $\begin{array}{l}0.4 \\
1.2 \\
2.0\end{array}$ & $\begin{array}{l}100.91 \\
101.24 \\
102.66\end{array}$ & 254.02 & 250 \\
\hline & $\begin{array}{l}\text { Kadomet } \\
\text { tablet }^{\mathrm{b}}\end{array}$ & $\begin{array}{l}0.4 \\
1.2 \\
2.0\end{array}$ & $\begin{array}{l}98.50 \\
99.58 \\
99.33\end{array}$ & 247.85 & 250 \\
\hline & $\begin{array}{c}\text { Dopamine. } \mathrm{HCl} \\
\text { injection }^{\mathrm{c}}\end{array}$ & $\begin{array}{l}0.2 \\
0.5 \\
1.0 \\
\end{array}$ & $\begin{array}{c}98.50 \\
102.46 \\
101.50\end{array}$ & 201.64 & $200 \mathrm{mg} / 5 \mathrm{ml}$ \\
\hline & $\begin{array}{l}\text { Adrenaline } \\
\text { injection }^{\mathrm{d}}\end{array}$ & $\begin{array}{l}0.5 \\
2.0 \\
4.0\end{array}$ & $\begin{array}{c}104.80 \\
99.58 \\
101.33\end{array}$ & 1.02 & $1.0 \mathrm{mg} / \mathrm{ml}$ \\
\hline \multirow{4}{*}{$\begin{array}{c}\text { British } \\
\text { Pharmacopoeia } \\
\text { method [31] }\end{array}$} & $\begin{array}{l}\text { Methyldopa } \\
\text { tablet }\end{array}$ & & 99.50 & 248.75 & 250 \\
\hline & $\begin{array}{c}\text { Kadomet } \\
\text { tablet }\end{array}$ & & 101.06 & 252.65 & 250 \\
\hline & $\begin{array}{c}\text { Dopamine. } \mathrm{HCl} \\
\text { injection }\end{array}$ & & 98.85 & 197.70 & $200 \mathrm{mg} / 5 \mathrm{ml}$ \\
\hline & $\begin{array}{l}\text { Adrenaline } \\
\text { Injection }\end{array}$ & & 99.20 & 0.99 & $1.0 \mathrm{mg} / \mathrm{ml}$ \\
\hline
\end{tabular}

* Mean of three determinations. ${ }^{\mathrm{a}}$ Marketed by S.D.I. Iraq; ${ }^{\mathrm{b}}$ Marketed by Kahira Pharm.; ${ }^{\mathrm{c}}$ Marketed by DEMO S.A.-Greece; ${ }^{\mathrm{d}}$ Marketed by Orion Pharmaceutica, Finland

\section{Conclusion}

The proposed method is simple, rapid, sensitive and economical compared to already reported methods and do not require any pretreatment of the drugs or extraction procedure and has a good accuracy and precision. On the other hand, in terms of sensitivity and expense, the method could be considered superior in comparison with the titrimetric British pharmacopoeia method and the previously reported methods, especially with those based on non-aqueous medium.

\section{Acknowledgment}

Many thanks to Dr. Theia'a N. Al-Sabha for help and for his big effort. 


\section{References}

[1] Yu C., Tang Y., Han X. and Zheng X. ,Anal. Sci., 22, 25-28, (2006).

[2] Kumarathasan P. and Vincent R., J. Chromatogr. A, 987, 349, (2003).

[3] Ragab G. H., Nohta H., and Zaitsu K., Anal. Chim. Acta, 403, 155, (2000).

[4] Hansen A., Krisfiansen J., Ly gsted Nielsen J., Byrialsen K., and Christensen J., Talanta, 50, 367 (1999).

[5] Wang Y.S., Fice D. S., and Yeung P. K. F., J. Pharm. Biomed. Anal., 21, 519, (1999).

[6] Sabbioni C., Saracino M. A., Mandrioli R., Pinzauti S., Furlanetto S., Gerra G., and Raggi M. A., J. Chromatogr., A, 1032, 65, ( 2004).

[7] Zhang L.Y., Qv S. F., Wang Z. L. and Cheng J. K., J. Chromatogr.,B, 792, 381,(2003).

[8] Wang H. Y., Sun Y. and Tang B., Chin. J. Anal. Lab., 22, 45, (2003).

[9] Wang H. Y., Hui Q. S., Xu L. X., Jiang J. G. and Sun Y., Anal. Chim. Acta, 497, 93 (2003).

[10] Wang H. Y., Sun Y. and Tang B., Talanta, 57, 899, (2002).

[11] Rubianes L.D. and Rivas G. A., Anal. Chim. Acta, 440, 99, (2001).

[12] Xu F., Gao M., Wang L., Shi G., Thang W., Jin L., and Jin J., Talanta,55, 329, (2001).

[13] Salem F. B., Anal. Lett., 18, 1063, (1985).

[14] El-Rabbat N. A., Omar N. M. , J. Pharm. Sci., 67, 779, (1978).

[15] Nagaraja P., Vasantha R. A., Murthy K. C. S.and Rangappa K. S., Chemia Analityczna 46, 569, (2001).

[16] Aman T., Khan I. U., Aslam N., Ahmed I., Anal. Lett., 31, 1007, (1998).

[17] Al-Ghabsha T. S., Salih E.S. and Al-Delami A.M., J. Ed. and Sci., 14,38,(2002). 


\section{Sensitive spectrophotometric method for...}

[18] Nevado J.J.B., Gallego J.M.L.and Laguna P.B., Frenesius J. Anal. Chem. 353, 21, (1995).

[19] Nagaraja P., Murthy K.C.S., Rangappa K. S., Gowda N. M. M., Talanta 46, 39, (1998).

[20] Nour El-Dien F. A., Zayed M. A., Mohamed G.G., and El-Nahas R.G., J. Biomed and Biotechnology, 1, 1, (2005).

[21] Vieira I. C. and Fatibello-Filho O., Talanta 46, 559, (1998).

[22] Issopoulos P. B. and Economou P. T., Farmaco 48, 127, (1993).

[23] Walash M. I., AbouOuf A. and Salem F. B., J. Assoc. Off. Anal. Chem. 68, 91 (1985).

[24] Nagaraja P., Vasantha R. A. and Sunitha K. R., Talanta 55, 1039, (2001).

[25] Issopoulos P. B., Pharm. Acta Helv., 64, 82, (1989).

[26] Al-Ghabsha T. S., Salih E.S. and Mohamad I.K., J. Ed. and Sci., $1,32,(2002)$.

[27] Al-Ghabsha T. S. and Salih E.S., J. Ed. and Sci., 16,71,(2004).

[28] Reddy M.N., Murthy T.K.and Rajita K., Shankar D.G., J.Pharm. Sci., $63,245,(2001)$.

[29] Rao J .V.L.N.S., Rao M .R.P.and Reddy Y .S.N., J. Pharm. Sci., 62, 318, (2000).

[30] Xuexin G., Chunhua C. and Tianze T., Fresenius J.of Anal.Chem., 355,94,(1996).

[31] British Pharmacopoeia 2000, Version 4, CD-ROM, Her Majesty's Stationery Office, PDF, p 26-37, 15-2, 1-36. 